\title{
SOUTH AMERICA: A RESERVOIR OF CONTINENTAL CARBON - FIRST ESTIMATE OF CHANGES SINCE 18,000 YR BP
}

\author{
H.Faure' \\ B.Volkoff \\ J.Argollo \\ L.Coltrinari ${ }^{4}$ \\ M.Fabre ${ }^{1 *}$ \\ L.Faure ${ }^{1}$ \\ N.Page' \\ G.Pedro ${ }^{2}$ \\ A.Ruellan ${ }^{5}$
}

\section{ABSTRACT}

By using geographic and palaeogeographic sketches established for the present situation (before recent deforestation) and for the glacial maximum (about 15,000-18,000 BP) we can estimate the possible total biomass (phytomass) of the South American continent. According to the biomass density used in this first estimate for ten major ecosystems, the results show a possible increase from 140 Gt of carbon (glacial maximum) to $214 \mathrm{Gt} \mathrm{C}$ (preindustrial) for the phytomass, and 120 to $180 \mathrm{Gt} \mathrm{C}$ for the soils.

These preliminary results are possibly only a 60 or 70 percent approximate estimate and could be modified with computation using other palaeogeographic models or another biomass density. It is

\footnotetext{
'Laboratoire de Géologie du Quaternaire-CNRS Luminy, Case 907, 13288-Marseille, France.

${ }^{2}$ ORSTOM, Services Scientifiques Centraux, 93140-Bondy, France.

${ }^{3}$ Servicio Geológico, Casilla 12198, La Paz, Bolivia.

${ }^{4}$ Departamento de Geografia/USP C.P. 8105, 01051-São Paulo, Brazil.

${ }^{5}$ Ministère de l'Agriculture, 66 rue Condorcet, 75009 Paris, France.

"deceased May 1989.
} 
therefore to underline the urgent need of more field biomass measurements, ecosystems mappings, and palaeostudies to evaluate the part of South America as a future possible sink for the atmospheric carbon dioxide.

The Amazonian forest makes of South America an important continental reservoir of carbon for the planet Earth.

This continent represents consequently a key zone for the research and knowledge of changes in the biogeochemical cycle of carbon. In order to evaluate more precisely the role it plays we estimated the approximate quantities of carbon in the total phytomass and the carbon in soils for each of the ecosystems represented in Figure 1, both for Present and Last Glacial Maximum landscapes.

\section{METHOD}

For first preliminary estimate a sketch map of the eight principal biomes or ecosystems of South America was organized (FAURE et al., 1985) based upon the palaeobioclimatic maps by HUECK (1972), AB'SABER (1977), BROWN \& AB'SABER (1979), and palaeopedological and geochemical maps by PEDRO \& VOLKOFF (1984). Two representation are given: one for the Present state (before the great deforestations), and another for a probable state during the end of the Last Glacial Maximum (18,000-15,000 yr BP), according to palaeoclimatic data of the authors. Areas of principal ecosystems were measured and the most probable biomass value was calculated for each ecosystem using the mean density values compiled for the Earth by AJJAY et al. (1979). These values are closer to more recent field measurements (MAURY-LECHON, 1982) and slightly higher than those from volumetric evaluation (BROWN \& LUGO, 1984).

\section{RESULTS}

Results in Table I allow to propose a first estimate of total biomass and organic matter of soils for South America, calculated in carbon, for two opposite climatic states. The lack of precision about the Present areas occupied by the ecosystems and their mean biomass causes an standard deviation of 30 $40 \%$. Considering the palaeogeographic documents and densities of carbon $/ \mathrm{m}^{2}$ we used for this preliminary estimate, the model for the Present situation gives a value of $214 \mathrm{Gt}\left(\mathrm{Gt}=\mathrm{Gigaton}=10^{15} \mathrm{~g}\right.$ ) of vegetal biomass, and 140 Gt for the Glacial Maximum; reduction of vegetal carbon would amount to $1 / 3$ during a glacial phase. It would be useful to recalculate these data with other palaeogeographic models and other biomass values to obtain a more precise standard deviation. 


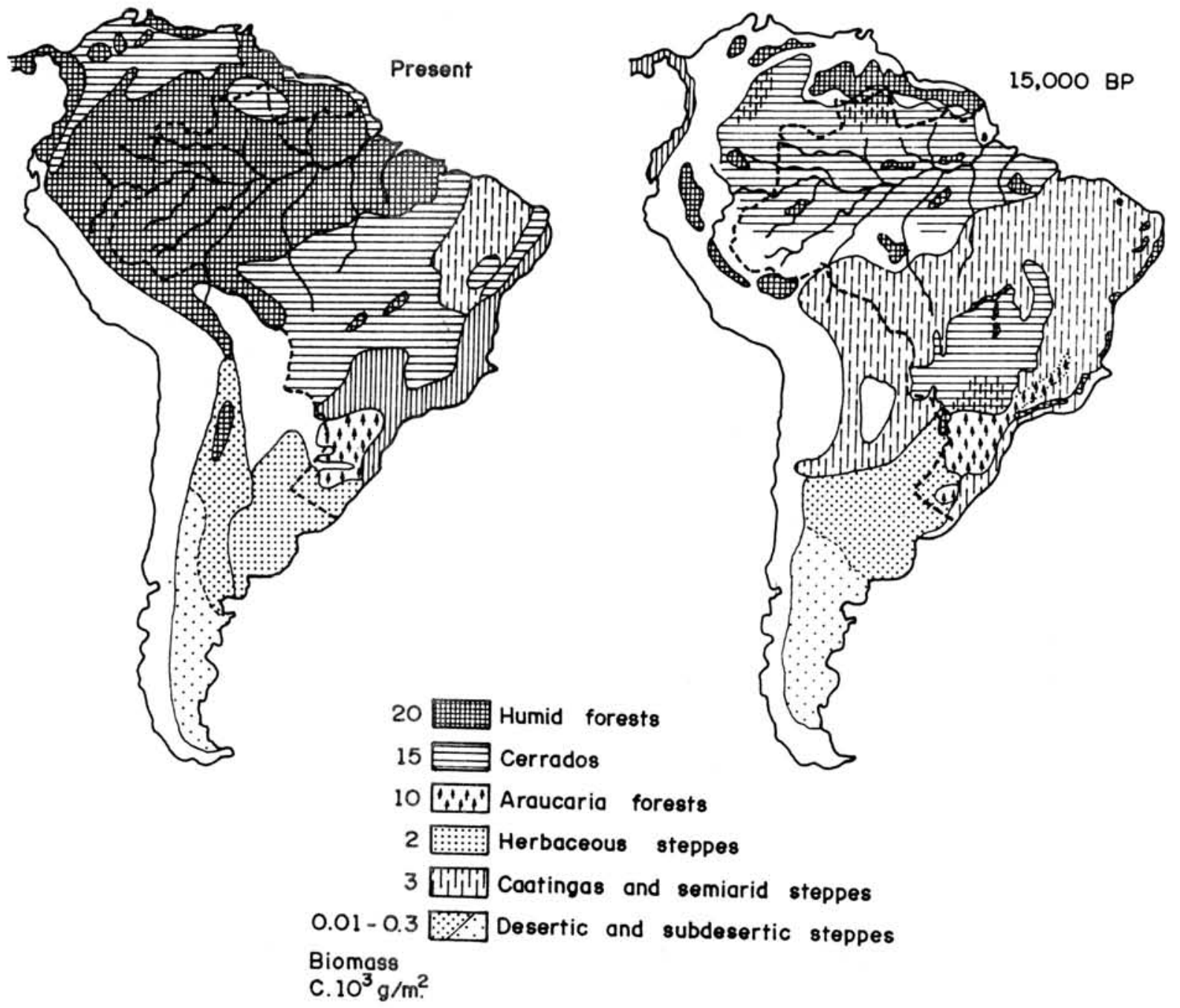

Figure 1 - Simplified map of the principal ecosystems in South America for a Glacial Maximum and for "Present". 
Table 1 - South America biomass. From left to righ: ecosystem, carbon density $/ \mathrm{m}^{2}$ (biomass in the soil upper meter), area (millions of $\mathrm{km}^{2}$ ), total biomass, total weight of soil carbon (carbon $\mathrm{Gt}$ ) for Present and for $18,000 \mathrm{BP}$.

\begin{tabular}{|c|c|c|c|c|c|c|c|c|}
\hline \multirow[b]{3}{*}{ Humid forests } & \multicolumn{2}{|c|}{ Mean composition } & \multicolumn{3}{|c|}{ Present situation } & \multicolumn{3}{|c|}{ Glacial situation $(18,000 \mathrm{BP})$} \\
\hline & $\begin{array}{r}\text { Biomass } \\
\mathrm{C}\end{array}$ & $\begin{array}{l}\text { Solls } \\
7^{2}\end{array}$ & $\begin{array}{l}\text { Surface } \\
\mathrm{Mkm}^{2}\end{array}$ & Biomass & Soil & $\begin{array}{l}\text { Surface } \\
\mathrm{Mkm}^{2}\end{array}$ & $\begin{array}{l}\text { Biomass } \\
\text { CGt }\end{array}$ & Soil \\
\hline & 20 & 15 & 6.4 & 128.0 & 96.0 & 1.7 & 34.0 & 25.5 \\
\hline Humid forests (coasts) & 20 & 15 & 0.4 & 8.0 & 6.0 & 0.2 & 4.0 & 3 \\
\hline Cerrados & 15 & 7 & 3.7 & 55.5 & 25.9 & 5.3 & 79.5 & 37.1 \\
\hline Araucaria forests & 10 & 15 & 1 & 10.0 & 15.0 & 0.9 & 9.0 & 12.5 \\
\hline Caatinga & 3 & 7 & 0.8 & 2.4 & 5.6 & 4.0 & 12.0 & 28 \\
\hline Herbaceous steppes & 2 & 12 & 1 & 2.0 & 12.0 & 0.0 & 0.0 & 0 \\
\hline Subdesertic steppes & 0.3 & 6 & 0.9 & 0.3 & 5.4 & 1.3 & 0.4 & 7.8 \\
\hline Desertic steppes & 0.01 & 1 & 0.8 & 0.0 & 0.8 & 1.1 & 0.0 & 1.1 \\
\hline Flooded, etc. & 8 & 10 & 0.9 & 7.2 & 9.0 & 0.2 & 1.6 & 2 \\
\hline Mountains, coastal deposits & 0.1 & 0.5 & 2 & 0.2 & 1.0 & 3.8 & 0.4 & 1.9 \\
\hline Total & & & 17.9 & 213.6 & 176.7 & 18.5 & 140.9 & 119.9 \\
\hline
\end{tabular}

About soils as carbon reservoirs a first continental estimate may be proposed. Considering timescales between 100-1,000 years it could be said that soil carbon content between 0-100 cm beneath the surface balances with the vegetation supported by that soil. From SANCHEZ et al. (1982) data and measures by CERRI \& VOLKOFF (1987) the carbon stock for the upper meter of soil has been calculated for each ecosystem. Table I shows that this stock represents today about $180 \mathrm{Gt}$; during the Last Glacial Maximum its value was probably about $120 \mathrm{Gt}$. A fluctuation of about 60 Gt could be estimated for this soil reservoir.

\section{COMPARISON}

Notwithstanding their preliminary character, these results can be compared to a previous estimate of the world continental biomass carbon (FAURE et al., 1989). Figures were calculated with a $30 \%$ estimated error for the world 1975 continental biomass, based upon AJJAY et al. (1979) values (Table II). The increase of the continental vegetation carbon reservoir from Last Glacial Maximum to Present would be of about 268 Gt (48 of Present); South American contribution would be about 73 Gt.

Table 2 - Changes in the carbon reservoir of continental vegetation (MGT of carbon).

Total forest phytomass

Total non forest phytomass

Total

$18.000 \mathrm{BP}$
106
186
292

292
Present (1975 A.D.)

428

132

560 


\section{CONCLUSIONS}

These approximations show important variations and should be improved. Therefore it is necessary to augment biomass and soil carbon evaluations; to continue with ecosystems cartography and dated palaeoclimatic studies in order to corroborate or to reconsider the role played by South America as a carbon reservoir, as well as the role it may play in the future to contribute to the maintenance of an adequate atmosphere for Man (Fig. 2). For the present preliminary results suggest that the glacial-to-interglacial carbon dioxide increase of about 200 Gt (BARNOLA et al., 1987) was accompanied by a similar or greater increase in the biosphere, and probably doubled by the soil carbon pool increase. In this global continental carbon increase South American contribution could be close to about $129 \mathrm{Gt}$ (in carbon).
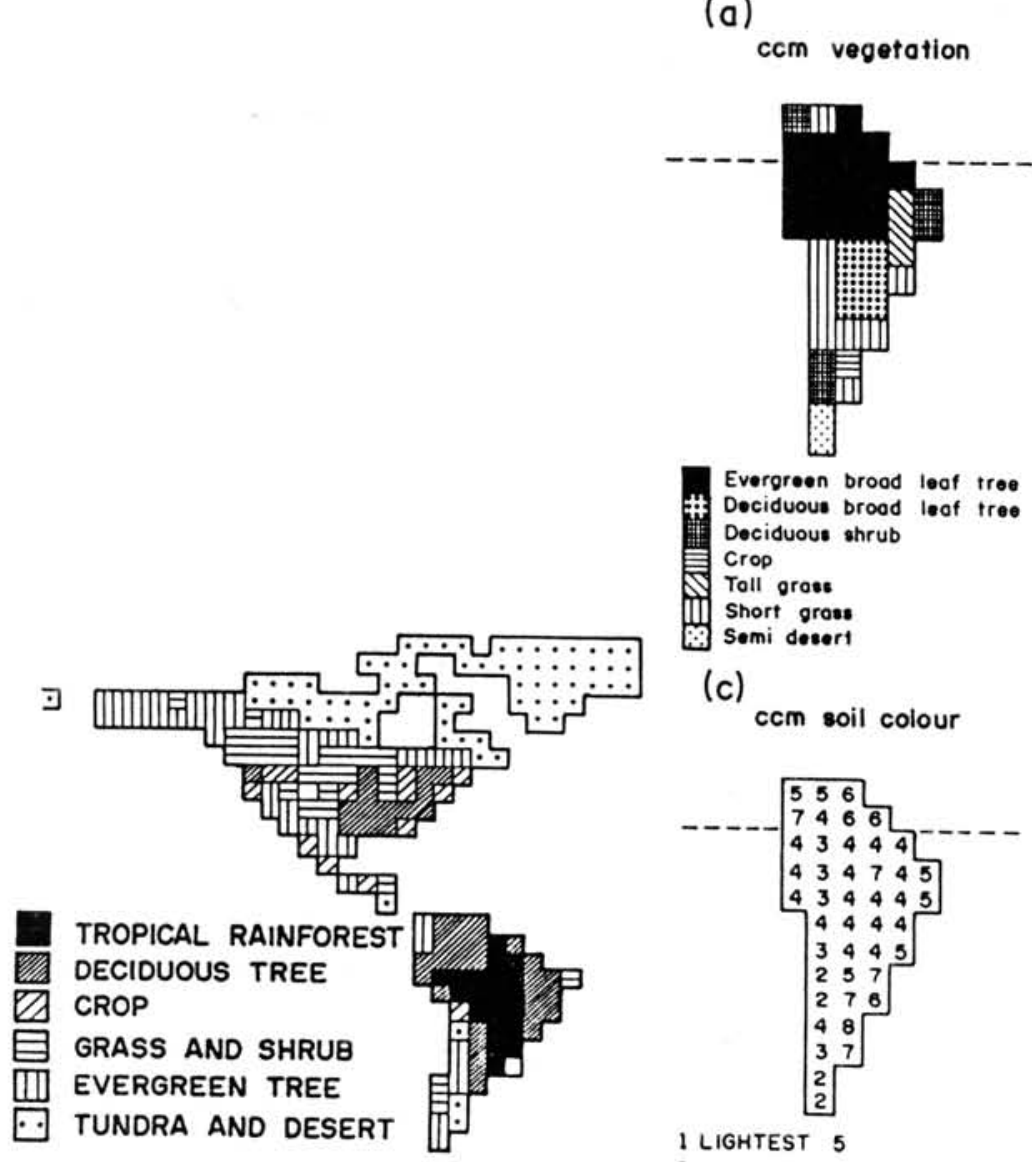

(c)

ccm soil colour

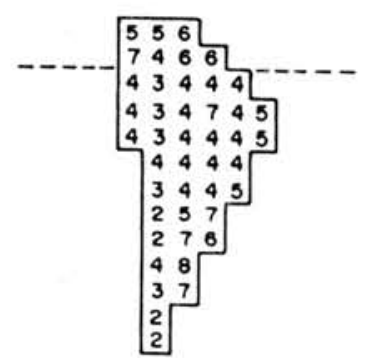

1 LIGHTEST 5

$\begin{array}{ll}2 & 6 \\ 3 & 7\end{array}$

. 4

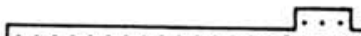
:.: (b)

ccm soil texture

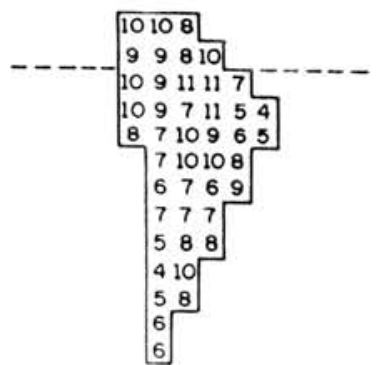

COARSEST 1 = SAND 7

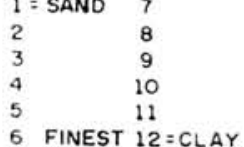

(d) ccm deforestation

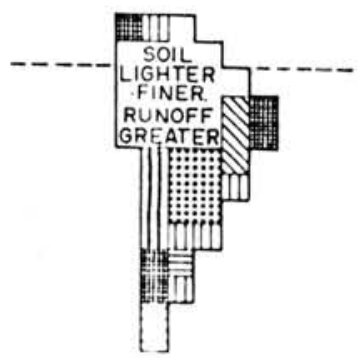

Key 08 in $\mathrm{ccm}$ vegetation

Figure 2 - There is an urgent need for maps giving the distributions of major ecotypes at precise dates in the Quaternary (from HENDERSON-SELLERS ot al., 1988). 


\section{REFERENCES}

AB'SABER, A.N. (1977) Espaços ocupados pela expansão dos climas secos na América do Sul por ocasião dos períodos glaciais quaternários. Paleoclimas, 3:1-19.

ABSY, M.L. (1979) A palynological study of Holocene sediments in the Amazon basin. Amsterdam (Ph.D.Thesis - University of Amsterdam).

AJJAY, G.L; KETNER, P.; DUVIGNEAUD, P. (1979) Terrestrial primary production and phytomass. In: BOLN, B.; DETGENS, E.T.; KEMPE, S.; KETNER, P. (eds.) The global carbon cycle Chichester. John Wiley, v.13. p.129-181.

BARNOLA, J.M.; RAYNAUD, D.; KOROTKEVICH, Y.S.; LORIUS, C. (1987) Vostok ice core provides 160,000 year record of atmospheric $\mathrm{CO}_{2}$. Nature, 327:477-482.

BAZILEVICH, N.I.; RODIN, LY.; ROZOV, N.N. (1971) What is the weight of the living matter of the Earth? Nature, 1:45-53.

BIGARELLA, J.J. \& ANDRADE, G.O. (1965) Contribution to the study of the Brazilian Quaternary. Special Paper. Geological Society of America, 84:433-451.

BINFORD, M.W. \& LEYDEN, B. (1987) Ecosystems, paleoecology and human disturbance in subtropical and tropical America. Quaternary Science Reviews, 6(2):115-129.

BOUN, B. (1981) Carbon cycle modelling. SCOPE, 16:1-390.

BORMANN, F.H. \& BERLYN, G. (1981) Age and growth rate of tropical trees: new directions for research. Bulletin Yale University, School of Forestry and Environmental Studies, 94:1-140.

BROWN, S. \& AB'SABER, A.N. (1979) Ice age forest refuges and evolution in the neotropics: correlation of paleoclimatological, geomorphological and pedological data with modern biological endemism. Paleoclimas, 5:1-30.

BROWN, S. \& LUGO, A.E. (1984) Biomass of tropical forest: a new estimate based on forest volumes. Science, 223:1290-1293. 
CERRI, C.C. \& VOLKOFF, B. (1987) Carbon content in a yellow latosol of central Amazon rainforest. Acta Oecologica, Ser. Geologia Generalis, 8(1):29-42.

COLNVAUX, P. (1987) Amazon diversity in light of the paleoecological record. Quatemary Science Reviews, 6(2):93-114.

DELCOURT, H.R. \& HARRIS, W.F. (1980) Carbon budget of the Southeastern U.S. biota: analysis of historical change in trend from source to sink. Science, 210:321-323.

FAURE, H.; FAURE, L; RUELLAN, A. (1985) Génèse de paysages brésiliens. Striolae, 1(7):20-22.

FAURE, H.; FABRE, M.; FAURE-DENARD, L; LFZINE, A.M.; PETIT-MAIRE, N. (1989) Une estimation de la biomasse globale a 18,000 ans B.P. In: COLLOQUE DE BIOGÉOGRAPHIE, ENVIRONNEMENT, AMÉNAGEMENT, Paris, 1988. Actes.

GUILLET, B.; FAIVRE, P.; MARIOTTI, A.; KHOZBI, J. (1988) The ${ }^{14} \mathrm{C}$ datings and ${ }^{13} \mathrm{C} /{ }^{12} \mathrm{C}$ ratios of soil organic matter as a means of studying the past vegetation in intertropical regions: examples in Colombia (South America). Palaeogeography, Palaeoclimatology, Palaeoecology, 65(1-2):51-58.

HENDERSON-SELLERS, A.; DICKINSON, R.E.; WILSON, M.F. (1988) Tropical deforestation: important processes for climate models. Climatic Change, 13:43-67.

LAMOTTE, M. \& BOURUERE, F. (1983) Tropical savannas. In: BOURLERE, F. (ed.) Ecosystems of the world. Amsterdam, Elsevier. 730p.

LESCURE, J.P.; PUIG, H.; RIERA, B.; SABATIER, D. (1983) Une forêt primaire de Guyane Française: donées botaniques. In: Le project ECEREX (Guyane): Analyse de l'ecosystème forestier tropical humide et des modifications apportées par l'Homme:132-177.

UETH, H. (1985) A dynamic model of the global carbon flux through the biosphere and its relation to climatic and soil parameters. International Journal Biometeorology, 29:17-31.

MAURY-LECHON, G. (1982) Régénération forestière en Guyane Française: recro sur 25 ha de coupe papetière en forêt dense humide (Arbocel). Revue Bois et Forêts des Tropiques, 197:3-21. 
OLSON, J.S.; WATTS, J.; ALUSON, LJ. (Carbon in live vegetation of major world ecosystems). Oak Ridge National Laboratory, USA. Environmental Sciences Division Publ. $\mathrm{n}^{\circ} 1997.164 \mathrm{p}$.

PEDRO, G. \& VOLKOFF, B. (1984) Grandes provinces pédologiques du Brésil. Cahiers O.R.S.T.O.M., Série Géologie, 14(2):169-188.

POST, W.M.; EMANUEL, W.R.; ZINKE, P.J.; STANGENBERGER, A.G. (1982) Soil carbon pools and world life zones. Nature, 298:156-159.

PRANCE, G.T. (1982) Biological diversification in the tropics. New York, Columbia University Press.

SANCHEZ, P.A.; GIGHURU, M.P.; KATZ. LB. (1982) Organic matter in major soils of the tropical and temperate regions. In: INTERNATIONAL CONGRESS OF SOIL SCIENCE, New Delhi, 1:99-114.

SAUGIER, B. (1986) Productivité des écosystèmes naturels. Biomasse Actualités. Numéro spécial, (9):4249.

SIOLI, H. (1985) The effects of deforestation in Amazônia. The Geographical Journal, 151(2):197-203.

SOLBRIG, O.T. (1987) Modeling responses of South American savannas to stress and disturbance: a research proposal. In: SIMPÓSIO SOBRE ECOSSISTEMAS DA COSTA SUL E SUDOESTE BRASILEIRA: SÍNTESE DOS CONHECIMENTOS. Anais, ACIESP nº 54-111, supl. 20p.

VAN DER HAMMEN, T. (1972) Changes in vegetation and climate in the Amazon Basin and surrounding area during Pleistocene. Geologie en Mijnbouw, 51:641-643.

VASEK, F.C. (1980) Creosote bush: long-lived clones in the Mojave desert. American Journal Botany, 67:246-255.

VUILLEUMIER, B.S. (1971) Pleistocene changes in the fauna and flora of South America. Science, 173:771-780.

WALKER, D. \& CHEN, Y. (1987) Palynological light on tropical rainforest dynamics. Quaternary Science Reviews, 6(2):77-92. 
WALTER, H. (1979) Vegetation of the Earth and ecological systems of the geo-biosphere. 2 ed. New York, Springer-Verlag. 274p. 